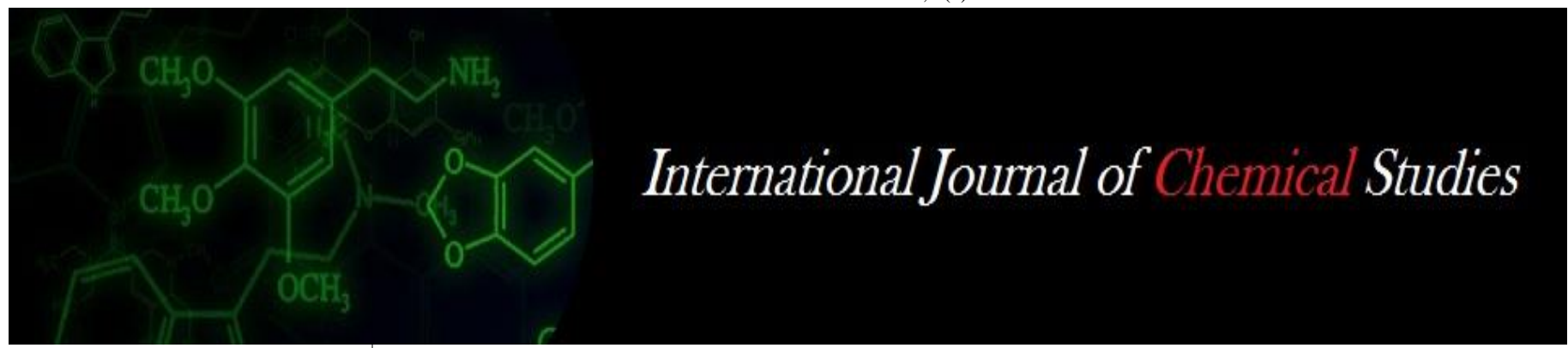

P-ISSN: 2349-8528

E-ISSN: 2321-4902

www.chemijournal.com

IJCS 2021; 9(1): 832-836

(C) 2021 IJCS

Received: 03-10-2020

Accepted: 09-11-2020

\section{Mumtaz Begum}

Department of Foods and

Nutrition, CCS Haryana

Agricultural University, Hisar,

Haryana, India

\section{Darshan Punia}

Department of Foods and

Nutrition, CCS Haryana

Agricultural University, Hisar,

Haryana, India
Corresponding Author: Mumtaz Begum

Department of Foods and

Nutrition, CCS Haryana

Agricultural University, Hisar

Haryana, India

\section{Effect of addition of Lotus stem powder on nutritional, phytochemical and antioxidant properties of sev}

\author{
Mumtaz Begum and Darshan Punia
}

DOI: https://doi.org/10.22271/chemi.2021.v9.i11.11326

\begin{abstract}
Lotus stem is highly nutritious, possessed antioxidant and anti inflammatory activities and prevent anaemia, PEM and osteoporosis. This study was aimed to utilize Lotus stem powder for the development of nutrients rich sev. LSP supplemented sev were developed by incorporating 10, 15, 20, 25 and 30 per cent of LSP and these were evaluated for sensory parameters, proximate composition, total and in vitro bio- accessible minerals and antioxidants. In terms of sensory parameters, LSP supplemented sev were adjudged between 'liked moderately' to 'liked very much' (Figure-2) and were acceptable by the judges. The contents of moisture, crude protein, crude fat, crude fibre, ash, total carbohydrates, total calcium, iron and zinc of best acceptable type-IV sev were 5.58, 13.05, 20.71, 2.97, 4.42, 53.27, 61.38, 5.67 and 3.06 per cent. Phytochemical (total phenolic content and total flavonoids content) and antioxidant capacity were also increased in supplemented sev. Results indicated that lotus stem powder can be successfully incorporated up to 25 per cent for the development of nutrient rich sev without compromising the sensory acceptability. LSP supplemented sev had significantly $(P<0.05)$ higher contents of fiber, calcium and iron than that of control sev.
\end{abstract}

Keywords: Nutrient rich, lotus stem, in vitro

\section{Introduction}

Lotus stem powder (LSP) have been considered nutritious as these are packed with high amounts of nutrients. The high amounts of lipid in seeds indicated their goodness in energy. Lotus stem is moderate in calories and rich in dietary fibre with complex carbohydrates which helps in lowering the blood glucose level and is recommended for pregnant women and people with chronic complains of constipation and also good for weight loss seekers (Ogle et al. 2001). Shad et al. $(2011)^{[13,16]}$ reported the lotus stem flour proximate composition $(\mathrm{g} / 100 \mathrm{~g}$ flour) as ash $(1.10 \pm 0.66)$, the total nitrogen $(1.36 \pm 0.04)$ total protein $(8.48 \pm 0.25)$, total sugar (19.08 \pm 0.01$)$ and free amino acids $(0.78 \pm 0.035)$. Park et al. (2009) investigated that lotus stem cultivars (Inchisa, Muan, Garam, and Chungyang) had high amounts of bioactive compounds: total phenols between $7.95 \pm 0.8$ and $4.21 \pm 0.3 \mathrm{mg}$ of gallic acid equivalents (GAE)/g dry weight, ascorbic acid between $15.8 \pm 1.1$ and $22.3 \pm 1.7 \mathrm{mg} / \mathrm{g} \mathrm{DW}$.

Gupta and Dubey (2013) ${ }^{[7]}$ evaluated the nutrient composition of lotus stem ladoo, puri and noodles with the incorporation of 40 per cent of lotus stem powder. In ladoo crude protein was $7.84 \mathrm{~g}$, fat $11.85 \mathrm{~g}$, crude fibre $6.29 \mathrm{~g}$, carbohydrates $50.58 \mathrm{~g}$ and iron $15.08 \mathrm{mg} / 100 \mathrm{~g}$. Lotus stem puri had protein $4.25 \mathrm{~g}$, fat $34.06 \mathrm{~g}$, fibre $5.54 \mathrm{~g}$, carbohydrates $48.55 \mathrm{~g}$ and iron $12.97 \mathrm{mg} / 100 \mathrm{~g}$. Lotus stem noodles at 40 per cent level of incorporation contained protein $6.4 \mathrm{~g}$, fat $17.85 \mathrm{~g}$, fibre $6.04 \mathrm{~g}$, carbohydrates $40.54 \mathrm{~g}$ and iron $14.99 \mathrm{mg} / 100 \mathrm{~g}$. In general, they are essential for growth, brain development and immune system. Additionally, LSP play a major role in preventing and treating anaemia because of the highest amount of iron hence being a key source of iron for vegetarians when consumed with vitamin C rich foods Dungarwal, (2019) ${ }^{[5]}$. Sev is a fried snack and quite popular among children who have been witnessed most malnourished. Generally it is made up of bengal gram flour mixed with spices and fried in oil. It is a high energy snack as it is fried however, with the supplementation of LSP it may also become rich in of iron and calcium and may be the best snacks for malnourished children. Keeping in view the above facts, efforts have been made to prepare LSP supplemented sev and to evaluate their sensory and nutritional properties. 


\section{Materials and Methods}

\section{Development and sensory evaluation of sev}

Lotus stem and other ingredients required for sev preparation were procured in a single lot from local market of Hisar city. The fresh lotus stem was cleaned manually and the damaged, inedible and brownish parts were discarded. The cleaned lotus stem was washed under running tap water to remove dust and dirt. It was rinsed with distilled water and spread over filter paper to remove extra water. Outer layer of stem was peeled with the help of stainless steel peeler, cut into small equal pieces and was spread on tray lined with filter paper. To evaporate the excessive moisture, it was dried in the hot air oven at $50 \pm 5^{\circ} \mathrm{C}$ till constant weight. The dried pieces were ground in electric grinder to obtain fine powder which was stored in Low Density Poly Ethylene (LDPE) bags till its further use in product development and analysis. Other ingredients used were bengal gram flour $(75 \mathrm{~g})$, ghee, red chilli powder, salt and oil to fry.

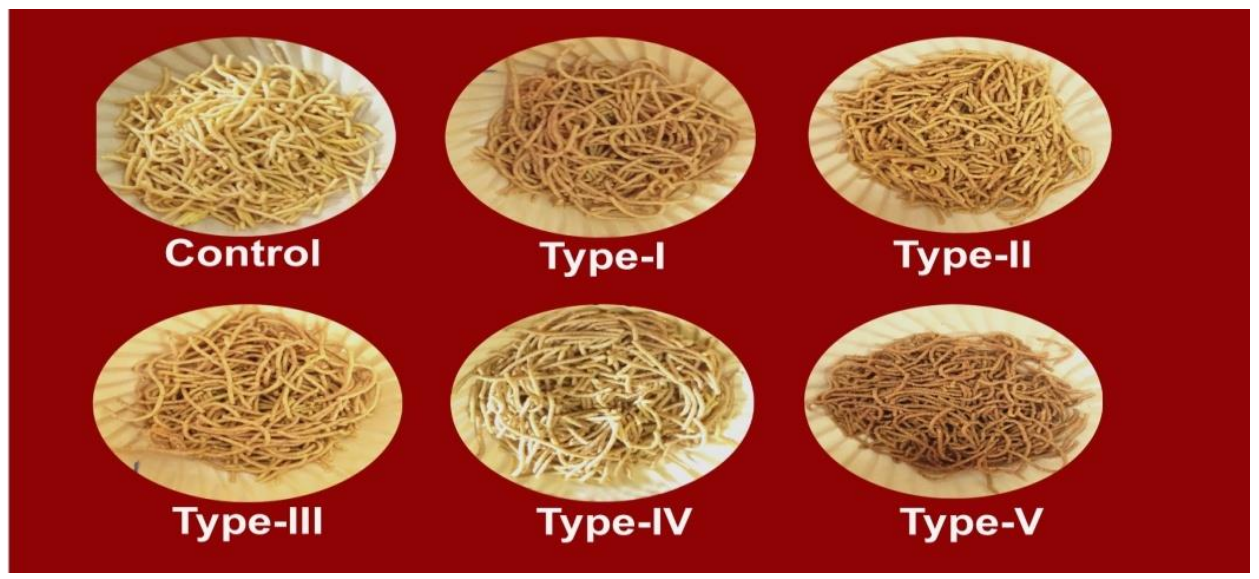

Plate 1: Preparation of lotus stem powder incorporated Sev

Control $=$ Bengal gram flour

Type $-\mathrm{I}=$ Bengal gram flour + lotus stem powder (90:10)

Type $-\mathrm{II}=$ Bengal gram flour + lotus stem powder $(85: 15)$

Type - III = Bengal gram flour + lotus stem powder $(80: 20)$

Type - IV = Bengal gram flour + lotus stem powder $(75: 25)$

Type $-\mathrm{V}=$ Bengal gram flour+ lotus stem powder (70:30)

Developed sev were subjected to organoleptic evaluation by a panel of 20 semi-trained judges from I.C. College of Home Sciences, Chaudhary Charan Singh Haryana Agricultural University, Hisar, Haryana. The judges were asked to rate the product on the basis of texture, aroma, colour, appearance and taste of sev by employing a nine-point hedonic rating scale. Overall acceptability was calculated by summing up and average of sensory parameters. Mean scores for all these characteristics were calculated.

\section{Nutritional Analysis of Sev}

Proximate composition i.e. moisture, protein, fat, crude fibre, ash were determined by employing the standard method of AOAC (2010) ${ }^{[1]}$. The contents of calcium, iron and zinc in acid digested samples explained above were determined by Atomic Absorption Spectrophotometer as per the method explained by Lindsey \& Norwell (1969) ${ }^{[12]}$. Available calcium and zinc were extracted by adopting methodology of Kim \& Zemel (1986) ${ }^{[9]}$. In vitro available iron and calcium was extracted according to the procedure explained by Rao \& Prabhavathi (1978) ${ }^{[15]}$. The concentration of total phenol of the methanolic extracts was determined by the FolinCiocalteau colorimetric method (Singleton et al., 1999) ${ }^{[20]}$. Flavonoids content in methanolic extracts was determined by aluminium chloride colorimetric method (Zhishen et al., 1999) [23]. Total antioxidant capacity of the methanolic extracts was determined by using Ferric Reducing Antioxidant Power (FRAP) Assay (Benzie and Strain, 1996) ${ }^{[2]}$ and modified by (Tadhani et al., 2009) ${ }^{[21]}$. The antioxidant activity of the extracts, on the basis of the scavenging activity of the stable DPPH free radical, was determined by the method followed by Brand-Williams et al. (1995) ${ }^{[3]}$ as previously described by Tadhani et al. (2009) ${ }^{[21]}$.

\section{Statistical Analysis}

Data of sensory evaluation and nutritional composition of Lotus stem powder supplemented sev were statistically analysed for analysis of variance in a complete randomized design (CRD) by OPSTAT software developed by Sheoran \& Pannu (1999) ${ }^{[17]}$.

\section{Results and Discussion}

As per the scores given to colour, appearance, aroma, texture and taste, the overall acceptability of control sev was higher than that of LSP supplemented sev. As per the scores of color, appearance, aroma, texture and taste the overall acceptability of control sev was 8.21. hence, these were adjudged as 'liked very much'. Mean scores of overall acceptability of type-I, type-II, type-III, Type-IV and Type-V cutlets varied from 7.44 to 6.63 , being highest for the type-IV sev and lowest for type-V sev. However, all the supplemented sev were adjudged between 'liked moderately' to 'liked very much' (Figure-2) and were acceptable by the judges. Drying is a common process applied for vegetables, to enhance their sensorial properties and nutritional value. It also improves shelf life, palatability and acceptability of developed products (Jain et al. 2016). A pleasant aroma was arised in the dehydrated lotus stem. Sharma and Chaudhary (2001) ${ }^{[19]}$ reported that the chapati prepared by them was most acceptable up to 10 per cent incorporation of lotus stem powder in terms of all the sensory parameters. Kumari (2018) ${ }^{[10]}$ reported that missi roti 
was acceptable up to 10 per cent of lotus stem powder incorporation and Verma and Jain (2012) prepared mathri with dehydrated vegetables including lotus stem powder shows higher overall acceptabilityat 7.0 per cent level of incorporation. Kumari and Kumari (2002) ${ }^{[11]}$ prepared ladoo and chapati with 20 per cent and mathri with 15 per cent of lotus stem powder for supplementation to adolescent girls. Chaudhary and Pareek (2010) ${ }^{[4]}$ found that 5 per cent lotus stem powder in khakare was most acceptable.

The contents of moisture, crude protein, crude fat, crude fibre, ash and total carbohydrates in sev prepared with 100 per cent bengal gram flour were observed as 5.83, 14.85, 21.57, 1.91, 3.24 and 52.60 respectively, ash and crude fibre were found to be increased significantly $(P \leq 0.05)$ after addition of lotus stem powder (Table 1). A non significant difference was observed for moisture, fat and total carbohydrates content between control and LSP supplemented sev. The contents of moisture, crude protein, crude fat, ash, crude fibre and total carbohydrates of type-IV sev were 5.58, 13.05, 20.71, 4.42, 2.97, and 53.27 per cent, respectively. Maximum contents of crude fibre and ash were observed in supplemented sev, whereas the maximum contents of crude protein was found in control sev. The contents of ash and crude fiber were increased significantly after lotus stem powder supplementation. Similarly Gupta (2014) ${ }^{[6]}$ revealed that replacement of 40 per cent lotus stem flour in wheat flour significantly increased the mineral content. The substitution of lotus stem powder for wheat flour to make biscuits showed considerable improvement in calcium and iron content (Yadav and Dunkwal 2014) ${ }^{[22]}$. Control ladoo had significantly lower values for bioavailable calcium and iron as compared to supplemented ones.

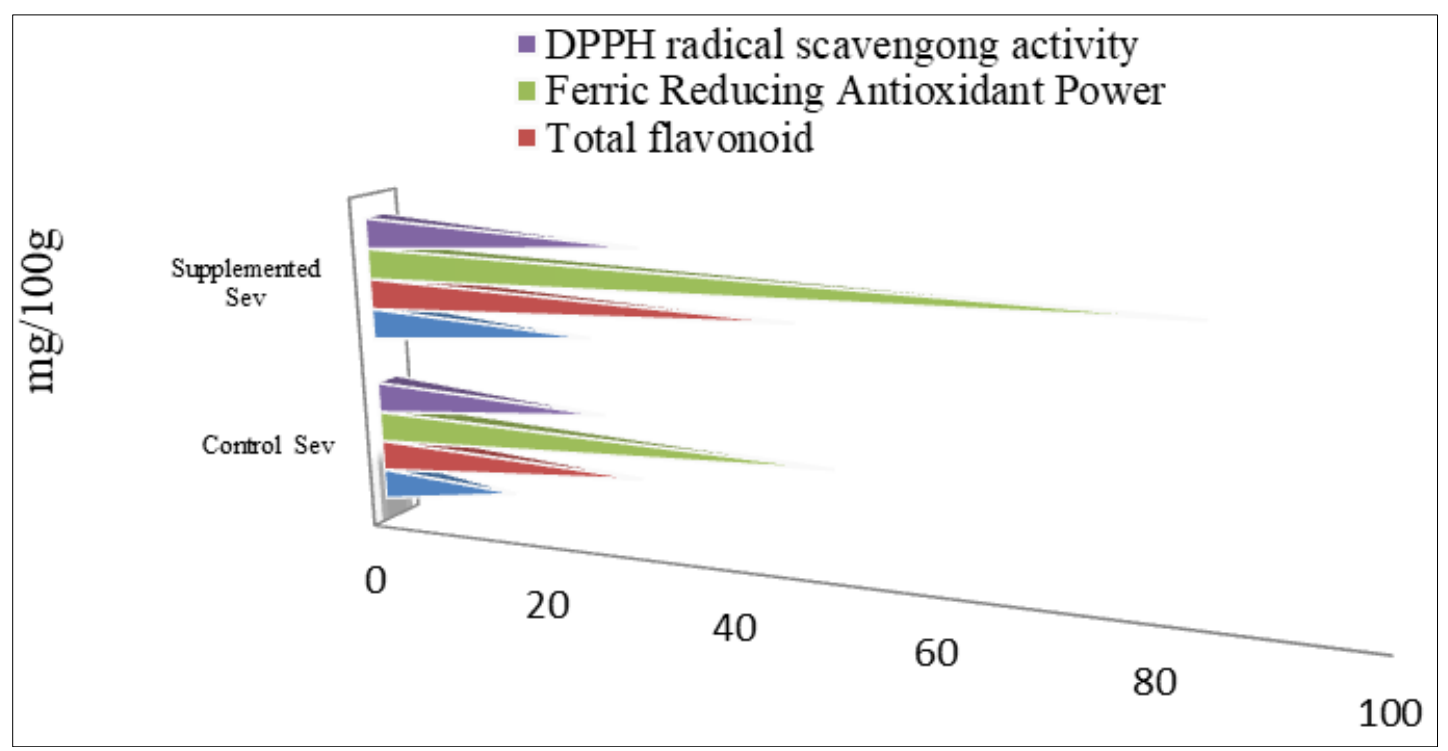

Fig 2: Antioxidant activity of sev products (fresh weight basis)

Total phenolic content and total flavonoids of type IV sev (23.63 mg GAE/100g, $44.97 \mathrm{mg} \mathrm{RE} / 100 \mathrm{~g}$, respectively) were significantly higher as compared to control sev (14.46 mg GAE/100g, $28.77 \mathrm{mg}$ RE/100g, respectively). Similarly, ferric reducing antioxidant power and the DPPH radical scavenging activity were found significantly higher in supplemented sev (82.83 $\mathrm{mg} \mathrm{TE} / 100 \mathrm{~g}$ and $29.17 \mathrm{mg} \mathrm{TE} / 100 \mathrm{~g}$, respectively) as compared to control sev (48.80 mg TE/100g and $24.90 \mathrm{mg}$ $\mathrm{TE} / 100 \mathrm{~g}$, respectively).

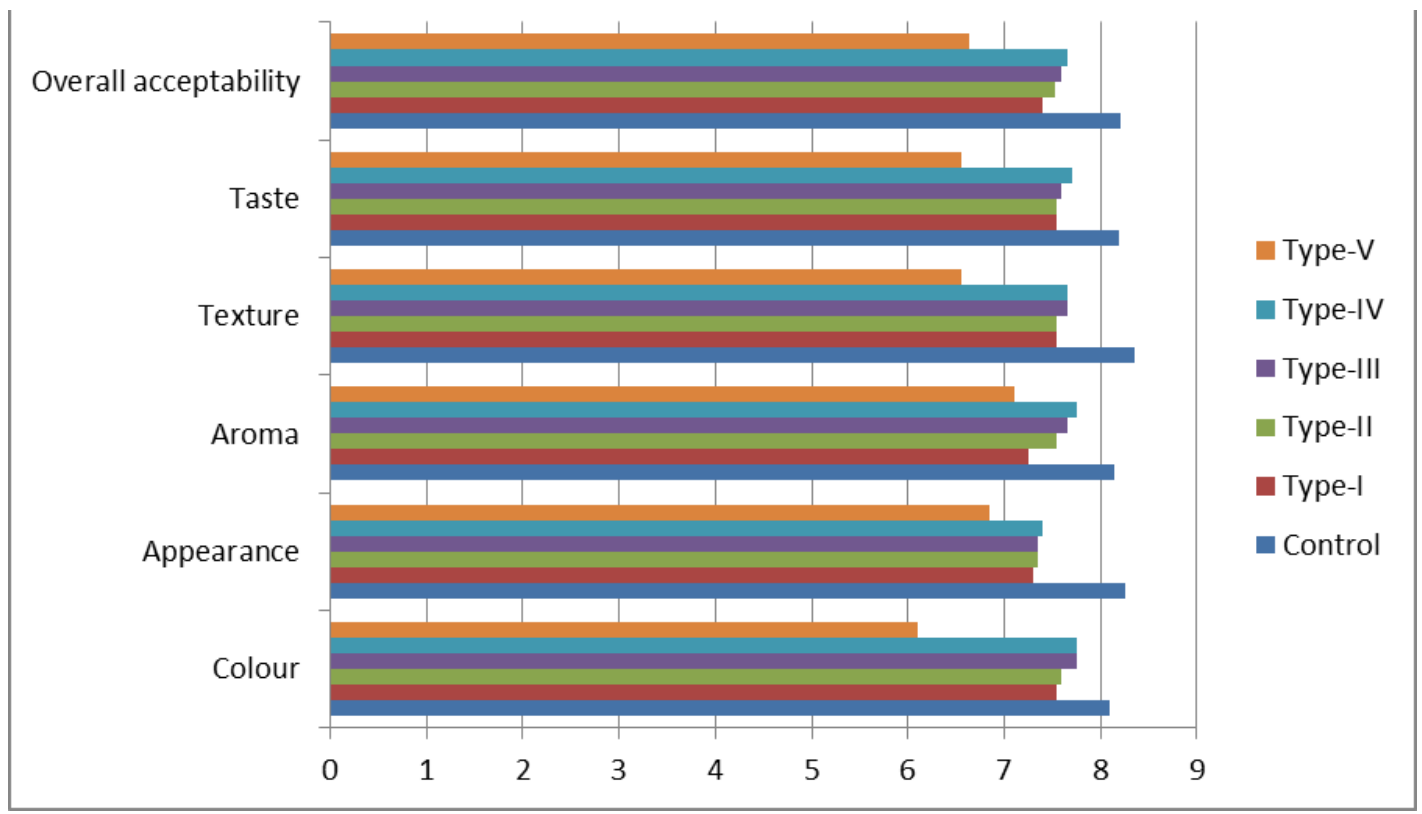

Fig 1: Sensory scores of lotus stem powder supplemented sev 


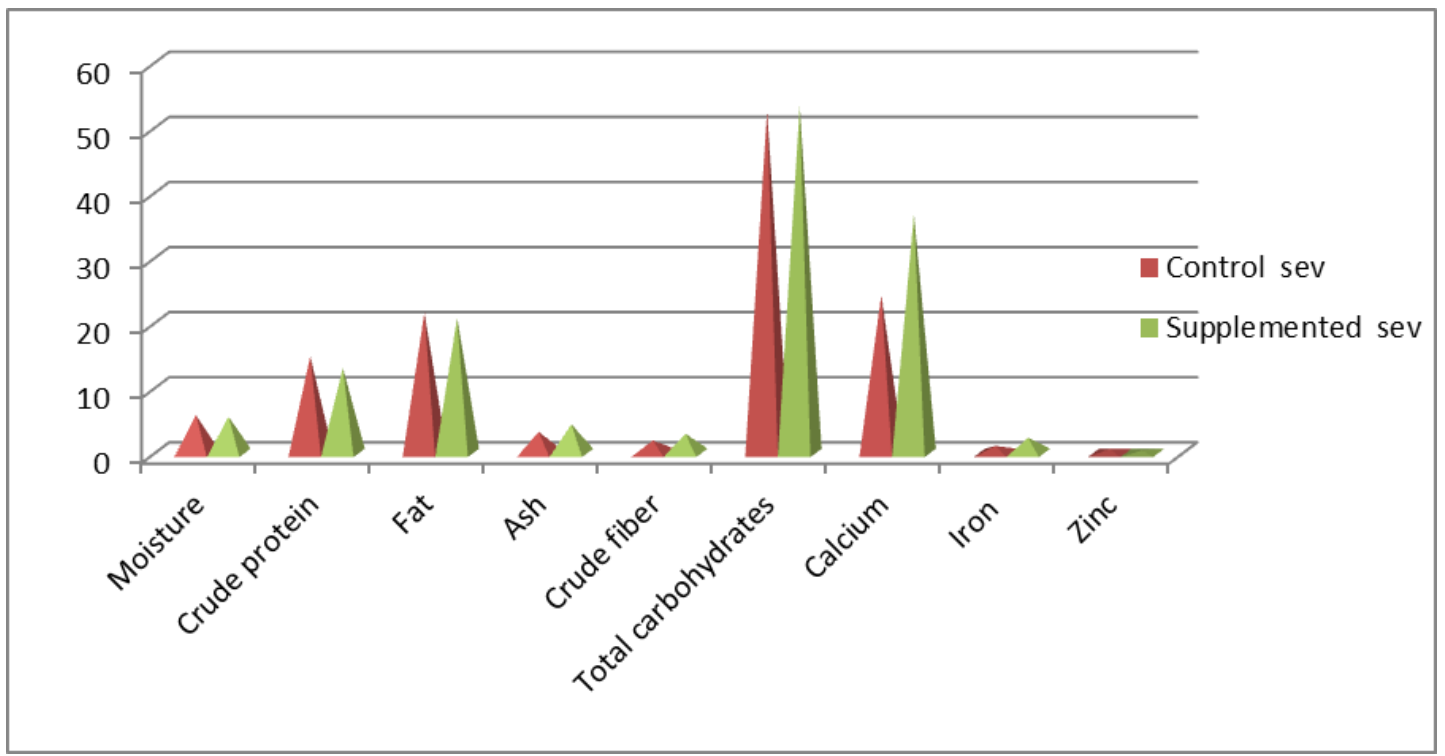

Fig 3: Proximate composition of lotus stem powder supplemented sev (\%, on dry weight basis)

Total Calcium, iron and zinc content of control sev was observed as 49.72, 3.74 and $3.76 \mathrm{mg} / 100 \mathrm{~g}$, respectively which were $61.38,5.67$ and $3.06 \mathrm{mg} / 100 \mathrm{~g}$, respectively in LSP supplemented sev. Type-IV sev had significantly $(P<0.05)$ higher contents of total calcium and iron. The per cent availability of calcium, iron and zinc among LSP supplemented sev was 59.72, 41.27 and 14.05 per cent, respectively. Similarly Gupta (2014) ${ }^{[6]}$ revealed that replacement of 40 per cent lotus stem flour in wheat flour significantly increased the mineral content. The substitution of lotus stem powder for wheat flour to make biscuits showed considerable improvement in calcium and iron content (Yadav and Dunkwal 2014) ${ }^{[22]}$. Control ladoo had significantly lower values for bioavailable calcium and iron as compared to supplemented ones.

\section{Conclusion}

It may be concluded that lotus stem is more acceptable when incorporated in sev than consumed as such as a salad. Dehydrated lotus stem powder can be successfully incorporated up to 25 per cent for the development of nutrient rich sev without compromising the sensory acceptability. LSP supplemented sev had significantly $(P<0.05)$ higher contents of fiber, calcium and iron than that of control sev. Consumption of lotus stem powder supplemented nutrient rich sev may improve the nutritional status in malnourished children and adolescents as anaemia is the major nutritional problem in India.

\section{References}

1. AOAC. Officials Methods of Analysis. Association of Official Analytical Chemists. Washington, D.C., U.S.A 2010.

2. Benzie IF, Strain JJ. The ferric reducing ability of plasma (FRAP) as a measure of "antioxidant power": the FRAP assay. Analytical Biochemistry 1996;239(1):70-76.

3. Brand-Williams W, Cuvelier ME, Berset C. Use of a free radical method to evaluate antioxidant activity. LWT Food Science and Technology 1995;28:25-30.

4. Chaudhary R, Pareek N. Enhancement of nutritional quality parameters and acceptability scores of soyblended product enriched with lotus stem powder. Food Science Research Journal 2010;1(2):56-59.
5. Dungarwal M. Iron intervention for improvement of iron status in adult female. International Journal of Research in Social Sciences 2019;9(6):756-764.

6. Gupta B. Nutritional enrichment of wheat flour based products by incorporation of carrot, lotus Stem, flax seed flour and admixture of these flours. Ph.D. Thesis. Department of Foods and Nutrition. Sam Higginbottom Institute of Agriculture Technology and Sciences, Allahabad, U.P, India 2014.

7. Gupta B, Dubey RP. Sensory attributes and nutritional value of the products prepared from lotus stem flour. Advances in Life Sciences 2013;2(2):58-60

8. Jain. Development of enteral feed using locally available foods and its suitability assessment. M.Sc. Thesis. Department of Foods and Nutrition, MPUAT, Udaipur, Rajasthan, India 2011.

9. Kim H, Zemel MB. In vitro estimation of the potential bioavailability of calcium from sea mustard, milk and spinach under stimulated normal and reduced gastric acid conditions. Journal of Food Science 1986;51(11):957963.

10. Kumari. Preparation and administration of healthy snacks for lifestyle diseases with emphasis on obesity: an interventional approach. $\mathrm{Ph}$. D Thesis. Department of Foods and Nutrition. Sam Higginbottom Institute of Agriculture Technology and Sciences, Allahabad, U.P, India 2018.

11. Kumari S, Kumari K. Effect of lotus stem (Nelumbo nucifera) stem in corporate production haemoglobin levels adolescent girls. M.Sc. Thesis. Department of foods and nutrition. Professor Jayashankar Telangana State Agricultural University, Telangana, India 2002.

12. Lindsey WL, Norwell MA. A new DPTA-TEA soil test for zinc and iron. Indian Agronomy Abstract 1969;61:84.

13. Ogle BM, Mulokozi G, Hambraeus L. Micronutrient composition and nutritional importance of gathered vegetables in Vietnam. International Journal of Food Science and Nutrition 2001;52(3):485-499.

14. Park Y, Towantakavanit K, Kowalska T, Jung S, Ham K, Gorinstein S. Bioactive compounds and antioxidant and antiproliferative activities of korean white lotus cultivars. Journal of Medicinal Food 2009;12(5):108-117. 
15. Rao NBS, Prabhavati T. Anin vitro method for predicting the bioavailability of iron from foods. American Journal of Clinical Nutrition 1978;31(3):169-175.

16. Shad M, Nawaz H, Hussain M, Yousuf B. Proximate composition and functional properties of rhizomes of lotus stem (Nelumbo nucifera) from Punjab, Pakistan. Pakistan Journal of Botany 2011;43(2):895-904.

17. Sheoran OP, Pannu RS. Statistical Package for agricultural workers. "O. P. Stat" College of Agriculture,

18. Kaul, CCS Haryana Agricultural University, Hisar. India 1999.

19. Sharma P, Chaudhary M. Development of an iron rich $\mathrm{rtm}$ powder from lotus stem and its acceptability in food preparations. Ph.D. Thesis. Department of Foods and Nutrition, MPUAT, Udaipur, Rajasthan, India 2001.

20. Singleton VL, Orthofer R, Lamuela RM. Analysis of total phenols and other oxidation substrates and antioxidants by means of Folin-Ciocalteu reagent. Methods in Enzymology 1999;299:152-178.

21. Tadhani MB, Patel VH, Subhash R. In-vitro antioxidant activities of Stevia rebaidiana leaves and callus. Journal of Food Composition and Analysis 2009;20:323-329.

22. Yadav S, Dunkwal V. Nutrient analysis of development iron rich premix and its product. Indian Journal Extension Education 2014;22:95-97.

23. Zhishen J, Mengcheng T, Jianming W. The determination of flavonoid contents in mulberry and their scavenging effects on superoxide radicals. Food Chemistry 1999;64:555-559. 